chapters of the book present a crisp, penetrating analysis of the shortcomings of prevalent theories about the exogenous impact of political culture and social capital, as well as a sharp empirical assessment of the measurement of social capital. This includes a demonstration that while league bowling may have been declining in the United States (then widely accepted as an indicator of the ebbing of social capital), there had been upsurges in other kinds of voluntary association across a wide variety of activities. The second half of the book explores the empirical impact of political institutions on political behavior by examining the effects of variation in political institutions on the rise of rightwing parties in Europe and on political participation.

Bob's contributions as a scholar and teacher were recognized with a number of awards. He was the recipient of fellowships from both the Guggenheim Foundation and the Center for Advanced Study in the Behavioral Sciences at Stanford, as well as two awards from the National Science Foundation. In 1988, Bob's achievements as a scholar and teacher were recognized by Michigan State University with the Distinguished Faculty Award. The breadth of Bob's recognition is perhaps best shown by the fact that between 1995 and 1998 he was simultaneously on the editorial boards of both the American Political Science Review and the American Sociological Review. Students and colleagues alike relied on him as a seemingly inexhaustible source on a broad array of intellectual and methodological issues, and his knowledge was always shared with generosity, incisiveness, and humility.

Bob's contributions to the Davis department are well known to his colleagues. He was committed to a cross-national, comparative perspective in his field of comparative politics. Although his own contributions to the field emphasized the importance of institutions, he was committed as well to the value of comparative behavioral work, and enthusiastically backed several hiring decisions that emphasized that side of the subfield. As a direct result of his leadership of the comparative field, the Davis department has porous boundaries between traditional subfields, and comparativists regularly collaborate with Americanists and international-relations scholars. Since Bob joined the Davis department, it has grown significantly in its vitality, intellec- tual energy, and collaborative spirit. Bob Jackman's contributions were critical to this progress, although if asked to assess his own importance to the department, his one-word response would likely have been, "exiguous." Bob was prized as a mentor by both graduate students and junior faculty. He spent many hours working individually with students and colleagues on research problems and career-related issues. His generosity and expansive intellect were immediately apparent to all who interacted with him. His teaching in the department spanned courses on comparative politics, methods, and American public opinion. A standing joke toward the end of the quarter when he was teaching public opinion was to ask which "level of conceptualization" he had managed to cover by that point in the course. His invariant response was a smile and say, "Still on level one." His unwavering commitment to scholarly principles, coupled with his broad and incisive intellect, communal generosity, and down-to-earth good humor, contributed significantly to the growth of the political science department at UC Davis.

Over the last two and a half years of his life, Bob fought his illness with the same quiet determination and dry humor that he had brought to all his endeavors. He strove to continue living his life as fully as he could, savoring the last undergraduate course that he taught (against medical advice) in the fall of 2008, continuing with scholarly collaborations, and maintaining his generous availability as a colleague and mentor.

But Bob was more than a political scientist. He was a lover of music who delighted in his regular attendance at concerts with the San Francisco Symphony. He was knowledgeable about automobiles and an avid reader of Car and Driver, making him much sought after for advice when it came time to buy a car. He loved to collect and work with old hand tools, which he often picked up after a tour through the listings on eBay. He retained the sense of practical self-sufficiency that he had acquired from his rural New Zealand childhood, and he got great satisfaction from all manner of carpentry, plumbing, and electrical projects around the home, always executed with finesse. He relished the physical beauty of California, especially the northern coast in Big Sur, San Francisco, and Mendocino, where he spent many happy days with his fam- ily and friends. He set great value in his friendships and he was a steadfast, loyal, and generous friend. In his personal and his professional life, he was a person of unusual warmth, self-deprecation, dry, understated humor, and quiet but fierce determination. He will be dearly missed by his family, colleagues, and friends, and by the many past and current graduate students of whom he was so proud.

Bob is survived by his wife Mary Jackman, professor of sociology at UC Davis; his daughter Rachael in San Francisco and son Saul in Palo Alto; his son-in-law Matt Munz in San Francisco; his brother and sister-in-law David and Margaret Jackman in Australia; his sister and brotherin-law Marian and John Vickerman and sister Helen Jackman in New Zealand; his brother-in-law and sister-in-law Paul Peretz and Jean Schroedel in Claremont, California; his niece and eight nephews in New Zealand, Australia, and California; and his mother-in-law Lil Peretz who migrated from Israel to Davis in 2001 with her (now deceased) husband Eddie to live with Mary and Robert.

A fund has been established in Bob's memory that will support the research activities of graduate students. Gifts should be made out to UC Regents and sent to: The Robert Jackman Memorial Fund, UC Davis, Department of Political Science \#106o, One Shields Avenue, Davis, CA 95616.

A memorial was held for Bob in Davis on December 6, 2009. There will also be a panel in honor of Bob's life, work and friendship at the Midwest Political Science Association meetings in Chicago in April 2010

Randolph M. Siverson
University of California, Davis
Walter J. Stone
University of California, Davis

\section{LORAN B. SMITH}

doi:10.1017/S1049096509990904

\section{Introduction, by Dr. Steven Cann, Washburn University}

Dr. Loran B. Smith passed away in Topeka, Kansas, on July 24, 2009. He was born on July 23, 1946. He was the son of Gordon T and Edith A (Hibbard) Smith of Medford, Massachusetts. Loran received his bachelors degree at Salem State College (Massachusetts) in 1968, a masters from 
Oklahoma State in 1971, and then taught at Black Hills State (Spearfish, South Dakota) from 1971-1974 and Augustana College in Souix Falls from 1974-1977. He received his Ph.D. from the University of Nebraska-Lincoln in 1980 and taught at Missouri Southern State College in Joplin until 1982. He then came to Washburn University of Topeka, where he taught until his death. While "Doc" Smith (as the students referred to him) published sufficiently enough to be awarded tenure and promotion to professor, that was not his forte. Loran was a gifted teacher. His CV lists 23 teaching awards, including Washburn's Faculty Certificate of Merit, a university-wide teaching honor based on student elections, from 1985-1998. Loran was also extremely active in faculty governance and other service to the university and the Topeka community. He was on the university's faculty governing body from 1996-2006, serving as its vice president in 2002 and president from 2003-2005. He was the chairman of the Social Science Division almost all of the 1990 and he also served as the chairman of the college's curriculum committee during that same time span. As Washburn is an open-admission university, we have retention problems not experienced by most universities. Loran researched, organized, and ran a college experience program for at-risk students. He was very active in ASPA, serving as the Kansas chapter president from 1987-1988, indeed, his auto license plate read "KS ASPA" and was purchased for him by students he had recruited into ASPA. Loran's main area of academic interest was state and local government and he was the election night expert for one of the local TV stations here in the capital of Kansas from 1984-1992. What occupied most of his time and energy outside of his official academic duties was serving as the faculty advisor for a local chapter of the Sigma Phi Epsilon fraternity. Doc Smith took what was a typical college fraternity and turned it into a modern association of men that consistently had the highest average GPA of all the fraternities and sororities on campus. It was not unusual for Loran to pay for a student's tuition and fraternity house bill, buy students books, and lend money to a needy student. Loran had a reputation for frugality (his apartment had a TV but no cable, a rotary phone, and he rented all of his furniture and appliances). Loran's tightness with money turned out to be a big benefit for the fraternity. One chapter offi- cial put it this way, "Through his notorious tight-fisted watch over finances, the Chapter was able to wipe out a significant debt to the National Housing Corporation ahead of schedule and helped the chapter build a significant savings by 2000." People who knew Loran thought that he was not married but Loran was married to his job. Not only was Loran in his office nearly every evening until 10:00 p.m., but he was there all day Saturday and Sunday too, and, more often than not, there was a student in that office talking with him.

What follows are what some of his former students had to say about Doc Smith.

\section{From Adam Breymeyer}

I'm not a famous graduate and will never be featured in the Washburn alumni magazine. Thanks to Loran Smith though, I am a Washburn alum. He took interest in a freshman on academic probation who had sat out a semester. If Loran hadn't taken on the role of mentor, I never would have seen graduation day. Hats off to Dr. Smith and I'll always try to "pay it forward."

\section{From Michael K. Moore, associate professor and senior vice provost, University of Texas at Arlington, and Washburn class of $\mathbf{1 9 8 7}$}

I received my alumni magazine today and was saddened to learn of Loran's death. Loran served as my academic advisor and mentor while I was at Washburn. Over the years we had a number of conversations about coursework and college life. He was extremely well suited for his role as a professor and advisor. I can honestly say that Loran played a significant role in my success at Washburn University and my subsequent career. I was on the debate team and like all debaters I assumed I was destined for law school and a career of professional arguing. That is, until I worked for a law firm the summer between my junior and senior years. I hated it and was terribly disillusioned. I don't think Loran was surprised by my experience and he saw in me a talent that I did not realize I had. He encouraged me to consider graduate school instead of law school and he recommended the University of Nebraska, his alma mater. In fact, since he still had contacts at UNL, he made a phone call on my behalf and I was awarded the Senning Fellowship-the top award to an incoming political science students. I am confi- dent it was due to his recommendation that I received the fellowship.

I decided to accept UNL's offer and earned both my MA and Ph.D. from the University of Nebraska. In 1992 I joined the faculty at the University of Texas at Arlington where I was later tenured and promoted to associate professor. Since 2000, I have been in the central administration and currently serve as the senior vice provost. I recall fondly my days at Washburn. I wanted to extend a special thanks to Dr. Smith for pushing me in the direction of graduate school-it was a wonderful fit for me and I hope I reach my students in the same way that he reached his.

\section{From Kendall R. Cunningham, Washburn University class of 1987 , JD 1990}

I met Dr. Loran Smith in the fall of 1984. I brashly walked into his office in the political science department at Washburn University and told him that I was going to law school and needed help getting there. Our subsequent conversation, as well as countless other conversations thereafter, is responsible for me being where I am today.

Dr. Smith challenged me by providing a roadmap that would point in the direction of law school. He suggested classes in multiple disciplines that would prepare me for the rigors of law school and put me in the best position to not only be admitted to law school, but to excel once I was there. He also encouraged me to be involved on campus, which led me to develop friendships that continue to the present.

Although I moved away from Topeka to begin my legal career, I continued to stay in touch with Dr. Smith to discuss my professional development, as well as the various challenges presented by life. Even today, as I handle my most difficult cases, the guidelines for success taught to me by Dr. Smith still ring true: work hard, be prepared, and never back down from a challenge. As a mentor and friend, he will be missed.

\section{From Stephen Ternes, Wichita}

I was saddened to read in the fall Washburn alumni magazine of the passing of Dr. Loran Smith. I graduated in 1987 with a BA in communications, a minor in political science, and went on to law school.

I remember Dr. Smith as a gentle, kind soul. Always chipper, he truly took a personal interest in his students. As I finished 
my degree, I stopped in his office one day to discuss the upcoming challenges of law school. He took me to lunch that day (he apologized that it could only be to the Union) and did his best to help me prepare. He even flattered the success I had achieved in my undergraduate studies. He paid for both of our lunches out of his own pocket. I was very impressed that a man of his importance had taken the time for a lowly undergrad.

I hope that he did not suffer in his passing. Dr. Smith and Washburn will remain in my prayers.

\section{From Rachel Goossen, Associate Professor of History, Washburn University}

In terms of his university and community service, Loran was deeply involved in the regional History Day program. He served as a judge at our District 3 competition, held here at Washburn, for more than 25 years, and enjoyed interacting with hundreds of middle school students over the years who created and interpreted visual exhibits on a wide range of historical topics.

\section{From Margie Mersmann}

I took several of Dr. Smith's classes in the mid-8os and I want to share with you my favorite quote of his. I returned to college after my children had all left home so I was an older student on campus. He would always tell me to "beware of little old ladies in tennis shoes, as you will never win an argument with them." I went on to get my BA in history in 1985 and taught school until my sixty-eighth birthday. He was my favorite teacher, and I remember him fondly. Thanks for listening.

\section{From Michael R. Brooks, Vice President and Chief Information Officer, CVR Energy}

Sorry to hear about Dr Smith. It was a pleasure to know him; he was always the first to put the students' education, welfare, and advancement above all else. I am fairly sure I would not have graduated without his counseling.

\section{FREDERICK MARSHALL WIRT}

\section{doi:10.1017/S1049096509990916}

Fred Wirt-a leading scholar of American politics for 30 years and a pillar of integrity in the University of Illinois' department of political science over that same span of time-died on August 21, 2009, in Coeur d'Alene, Idaho, at the age of 85 .

Professor Wirt was born in Radford, Virginia, on July 27,1924 . He was the first in his family to graduate from high school, and at the age of 18 he enlisted in the U.S. Army. His service during World War II was not unique, but it was sufficiently noteworthy by any objective standard. As a tank commander in the European theatre he participated in the Battle of the Bulge after which he and his colleagues liberated the Mathausen extermination camp where they saw firsthand thousands of the dead and dying littering the landscape in that chamber of horror. Among those whom Fred Wirt and his comrades saved were Simon Wiesenthal, the intrepid Nazi hunter, and Itzchak Tarkay, the distinguished artist. This incident would burn in his consciousness for the remainder of his life. Such was its impact that for the first 40 years of his marriage, he was unable to share the experience with his wife. The 21-year-old, who to that moment had perhaps never even met a Jew, would become in later years a fierce antagonist of anyone who dared question whether the Holocaust had actually occurred. After his European tour of duty, Fred was slated for service in the Pacific Theatre, and he always said that President Truman's decision to drop an atomic bomb on Hiroshima spared him and countless others from having to storm the beaches of Honshu.

Upon his return to civilian life, Professor Wirt attended and graduated from DePauw University in 1948 , where he met Betty Cook, whom he married in his junior year. Betty would be his staunchest and proudest supporter throughout the many challenges awaiting him in a marriage that stood the test of 62 years. He subsequently earned a Ph.D. in political science from The Ohio State University, and he often spoke of David Spitz, a star member of that faculty, in the most glowing terms. His dissertation on the government regulation of film censorship was eminently publishable, but I think Fred was simply thrilled to have the degree in hand after negotiating so many military and academic turnstiles and to get an opportunity to join a good teaching department. From 1952-1969, he was a member of the faculty at Denison University where he rose through the ranks and became a leading figure on campus.

Then lightning struck. Taking advantage of a 1967-1968 sabbatical leave, Professor Wirt established an affiliation with
Berkeley's Institute of Government Studies and underwent what he called a "mindbending experience." His mentors were Aaron Wildavsky and Nelson Polsby. Over and over again, I heard him extol their virtues: breadth of knowledge and intellectual stature, ambition, strength of opinion, and power of personality. Their respect for him was confirmed by the fact that they subsequently arranged a three-year (19691972) appointment on his behalf at the institute. It is perhaps a coincidence that Spitz, Wildavsky, and Polsby were all Jewish. I'll never believe it.

One could undertake the deplorable exercise of judging Professor Wirt's contributions to the literature by counting the number of his books (19 if a broad constructionist) and the number of his articles and book chapters (over 50 if similarly inclined), as if he were presenting his career statistics to the Baseball Hall of Fame's selection committee. (Fred would find this an apt analogy; he was an exceptional baseball player in his youth, and I think he had a tryout with a minor league team.)

Better to consider the political climate during his Berkeley residency (1969-1972). The key domestic issue was race relations. The Supreme Court had ordered the public schools of the nation to desegregate and Congress had passed the Civil Rights Act of 1964. What were the actual effects of these initiatives, of these public policies, Fred wanted to know. His desire to assess the place of African Americans in the public life of this nation flowed naturally from his need to appreciate the status and standing of Jews here and elsewhere. He began by co-editing a collection of essays entitled Northern School Desegregation (Chandler, 1968). Back then, though, the critical battlefield was the South, the home of George Wallace and his constituency. Fred made Panola County, Mississippi, his laboratory for studying the impact of civil rights legislation. Consider: here was a Clevelandraised academic traveling to a hotbed of racial animosity to interview white folk about their attitudes and behaviors toward black folk, this at a moment when the bodies of other northern whites were turning up here and there in the Deep South. His monumental study, Politics of Southern Equality (Aldine, 1970), was officially designated by the American Political Science Association for honorable mention status in the 1971 Woodrow Wilson best book 